\title{
ELEMENTAL AND MINERAL COMPOSITION OF ASH-SLAG WASTES OF SLOVIAN SKA THERMAL POWER PLANT
}

\author{
Elina Khobotova ${ }^{1}{ }^{*}$, Marina Ignatenko ${ }^{1}$, Vasiliy Larin ${ }^{1}$, Yulia Kalmykova ${ }^{1}$, \\ Anatoly Turenko'
}

https:

\begin{abstract}
Elemental, mineral and radionuclide composition of the Slovianska thermal power plant ashslag has been determined. The ash-slag fractions refer to the first class of radiation safety. The quantitative oxide composition is the following: $\mathrm{SiO}_{2}, \mathrm{Al}_{2} \mathrm{O}_{3}, \mathrm{Fe}_{2} \mathrm{O}_{3}, \mathrm{CaO}$ and $\mathrm{MgO}$. The granulometric fractions of wastes can be recommended as the components of light concretes.
\end{abstract}

Keywords: fuel ash, slag, fraction, mineral, radioactivity.

\section{Introduction}

The low-waste technologies stimulate the use of industrial wastes in various branches of industry. Blastfurnace slag has the properties of effective broken slag [1] and can be used for manufacturing various types of cement [2-4].

Wastes of the power engineering industry are fuel ash and slag. Thermal power plants (TPP) of Ukraine are large-scale sources of ash-slag wastes. Their accumulation in ash dumps increases every year. Recycling of ash and slag is technically and economically feasible as the location of thermal power plants in densely populated industrial areas of Ukraine makes it possible to use wastes in the construction industry.

Ashes from TPP carry-over are widely used for manufacturing cement [5] and various types of concrete [6-8], for manufacturing bricks and light porous fillers, as well as in road building [9]. However, at the majority of TPP ashes and slag are removed hydraulically. Thus, the ash-slag being inhomogeneous by its structure and properties gets into dumps, which complicates its further use.

The conclusion about the use of ash and slag for some definite purposes can be made only after preliminary determination of their elemental, chemical and mineral composition as well as granularity [10].

\footnotetext{
${ }^{1}$ Kharkiv National Automobile and Highway University, 25, Yaroslava Mudrogo St., 61002 Kharkiv, Ukraine

* chemistry@khadi.kharkov.ua

(C) Khobotova E., Ignatenko M., Larin V., Kalmykova Yu., Turenko A., 2017
}

Identification of the class of ash-slag wastes radiation safety is also of great importance. Ashes and slag are the components of the technogenically changed radiation background. Their uncontrollable application in the manufacturing of building materials can increase the gamma radiation intensity, external irradiation doses due to electromagnetic radiation, and the internal irradiation doses while inhaling radon isotopes $[10,11]$.

The aim of the research was to make a conclusion whether ash and slag wastes of Slovianska TTP could be used in construction based on determination of their elemental, chemical and mineral composition.

\section{Experimental}

The object of the research was the ash-slag wastes of the Slovianska TTP.

Distribution of ash-slag samples by granulometric fractions was carried out by means of sieve sets. The granularity of ashes varies widely. More often ashes of hydro dumps have a polydisperse composition with predomination of small fractions [12]. The maximum size of ash particles is $0.2 \mathrm{~mm}$. We distinguished the following fractions: $10-20 \mathrm{~mm}, 5-10 \mathrm{~mm}$ and $<5 \mathrm{~mm}$. Thus, all ash particles are transformed into the smallest fraction $<5 \mathrm{~mm}$, two other fractions include slag particles.

The research was conducted by the following methods: gamma-spectrometric, $x$-ray phase and chemical analysis, electron microprobe analysis.

\section{Results and Discussion}

\subsection{Gamma-Spectrometric Research of Ash-Slag Wastes}

Gamma-spectrometric analysis was performed on the scintillation gamma spectrometer SEG-001 "AKP-S", which measures the range of energy of gamma radiation from 50 to $3000 \mathrm{keV}$. The time of measuring activity of natural radionuclides makes up $4 \mathrm{~h}$ on average. To process the results of measurement Akwin program was used. The 
results of gamma-spectrometric analysis of ash-slag wastes have shown that their fractions include ${ }^{40} \mathrm{~K}$ and two representatives of radioactive families ${ }^{226} \mathrm{Ra}$ and ${ }^{232} \mathrm{Th}$ (Table 1). The isotope ${ }^{40} \mathrm{~K}$ share is the biggest in the total activity (more than $80 \%)$. Efficient specific activity $\left(C_{e f}\right)$ of slag fractions does not practically change as well as the content of particular radionuclides in it. Hence, there can not be a restriction in the use of particular granulometric fractions in construction. According to $C_{e f}$ values of ash-slag and its particular fractions, they refer to the first class of radiation safety at the value of $C_{e f} \leq 370 \mathrm{~Bq} / \mathrm{kg}$ [13]. Such materials can be used in construction without restriction.

\subsection{Electron Probe Microanalysis of Ash-Slag Fractions}

Electron microprobe analysis (EMPA) was carried out by the scanning electron microscope JSM-6390 LV INCA with the system of INCA X-ray microanalysis.

The X-ray microanalysis gives an idea about the elemental composition of fractions. The fraction $<5 \mathrm{~mm}$ includes $28.92 \%$ of carbon unlike larger slag fractions, which do not include any organic components. Then we decreased the quantity and obtained: silicium $(9.46 \%)$, aluminium $(4.72 \%)$ and iron $(3.92 \%)$. As the majority of elements are present as oxides, the content of oxygen makes up $48.86 \%$ (Table 2).

The method makes it possible to study the morphological features of the sample surface. Conglome-

rates of aggregates sintered with each other in contact are the prevailing spatial form (Fig. 1). The availability of organomineral aggregates in fractions worsens the quality of ash from the perspective of its use in concrete. The fraction of 5-10 mm includes mineral aggregates.

The microelemental analysis showed the full absence of organic components. The mass fraction of silicon $(17.7 \%)$ follows oxygen $(63.87 \%)$, then come aluminium $(8.8 \%)$ and iron $(3.59 \%)$. The silicon content has increased by 1.87 times, aluminium -1.86 times, the iron content has practically not changed in comparison with the fraction $<5 \mathrm{~mm}$. The predominant spatial form is the sintered racemose aggregates with the semi-sintered external cover that are formed as a result of the incomplete process of external sintering.

The results of the electron microprobe analysis of the $10-20 \mathrm{~mm}$ fraction prove the absence of any organic components. Silicon (19.96\%), aluminium $(12.19 \%)$, iron $(4.94 \%)$, and potassium $(2.26 \%)$ have the highest mass percentage after oxygen. The silicon content increased by 1.13 times, aluminium - 1.39 times, iron 1.38 times, and potassium - 1.65 times in comparison with the $5-10 \mathrm{~mm}$ fraction. $\mathrm{K}_{2} \mathrm{O}$ is an undesirable component in ashes if it is considered from the perspective of its use in building materials. The spatial structure of slag particles is presented by vitrified aggregates filled with sintered ash balls of various sizes (Fig. 2). Thus, aggregates of the fractions of 5-10 $\mathrm{mm}$ and 10-20 mm look like the sintered ash-slag formations with a wide variation of the ash particles sizes.

Table 1

The results of gamma-spectrometric analysis of fractions of ash-slag wastes from the Slovianska TTP

\begin{tabular}{|c|c|c|c|c|c|}
\hline \multirow{2}{*}{ Fraction, $\mathrm{mm}$} & \multirow{2}{*}{$C_{e f .}, \mathrm{Bq} / \mathrm{kg}$} & \multirow{2}{*}{$C_{\text {sum. }}, \mathrm{Bq} / \mathrm{kg}$} & \multicolumn{3}{|c|}{$C_{i}, \mathrm{~Bq} / \mathrm{kg}(\%$ content $)$} \\
\hline & & & ${ }^{40} \mathrm{~K}$ & ${ }^{226} \mathrm{Ra}$ & ${ }^{232} \mathrm{Th}$ \\
\hline$<5$ & 237 & 897 & $745(83 \%)$ & $83.4(9.3 \%)$ & $68.6(7.6 \%)$ \\
\hline $5-10$ & 269 & 984 & $807(82 \%)$ & $104(10.6 \%)$ & $72.9(7.4 \%)$ \\
\hline$>10$ & 264 & 966 & $792(82 \%)$ & $100(10.4 \%)$ & $73.5(7.6 \%)$ \\
\hline
\end{tabular}

Table 2

The results of the electron microprobe analysis of fractions of the Slovianska TTP ash-slag wastes (mass part)

\begin{tabular}{|c|c|c|c|}
\hline \multirow{2}{*}{ Element } & \multicolumn{3}{|c|}{ Fraction, mm } \\
\cline { 2 - 4 } & $<5$ & $5-10$ & $10-20$ \\
\hline $\mathrm{C}$ & 28.92 & 0.00 & 0.00 \\
\hline $\mathrm{O}$ & 48.86 & 63.87 & 56.75 \\
\hline $\mathrm{Na}$ & 0.43 & 0.96 & 0.79 \\
\hline $\mathrm{Mg}$ & 0.45 & 1.27 & 0.94 \\
\hline $\mathrm{Al}$ & 4.72 & 8.80 & 12.19 \\
\hline $\mathrm{Si}$ & 9.46 & 17.70 & 19.96 \\
\hline $\mathrm{S}$ & 0.27 & 0.10 & 0.35 \\
\hline $\mathrm{Cl}$ & 0.10 & 0.00 & 0.00 \\
\hline $\mathrm{Ca}$ & 1.18 & 1.37 & 2.26 \\
\hline $\mathrm{Ti}$ & 1.40 & 2.10 & 1.34 \\
\hline $\mathrm{Fe}$ & 0.28 & 0.23 & 0.48 \\
\hline
\end{tabular}



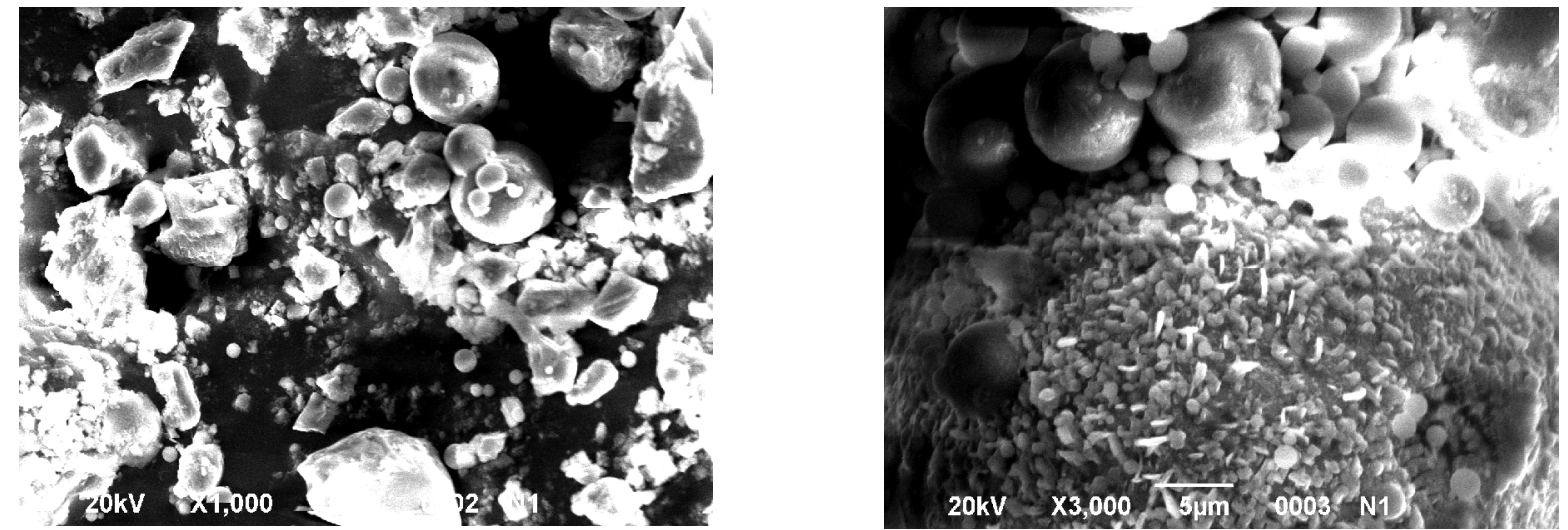

Fig. 1. The particles surface of the $<5 \mathrm{~mm}$ fraction of the Slovianska TTP ash-slag. Magnification of 1000x (a) and 3000x (b)
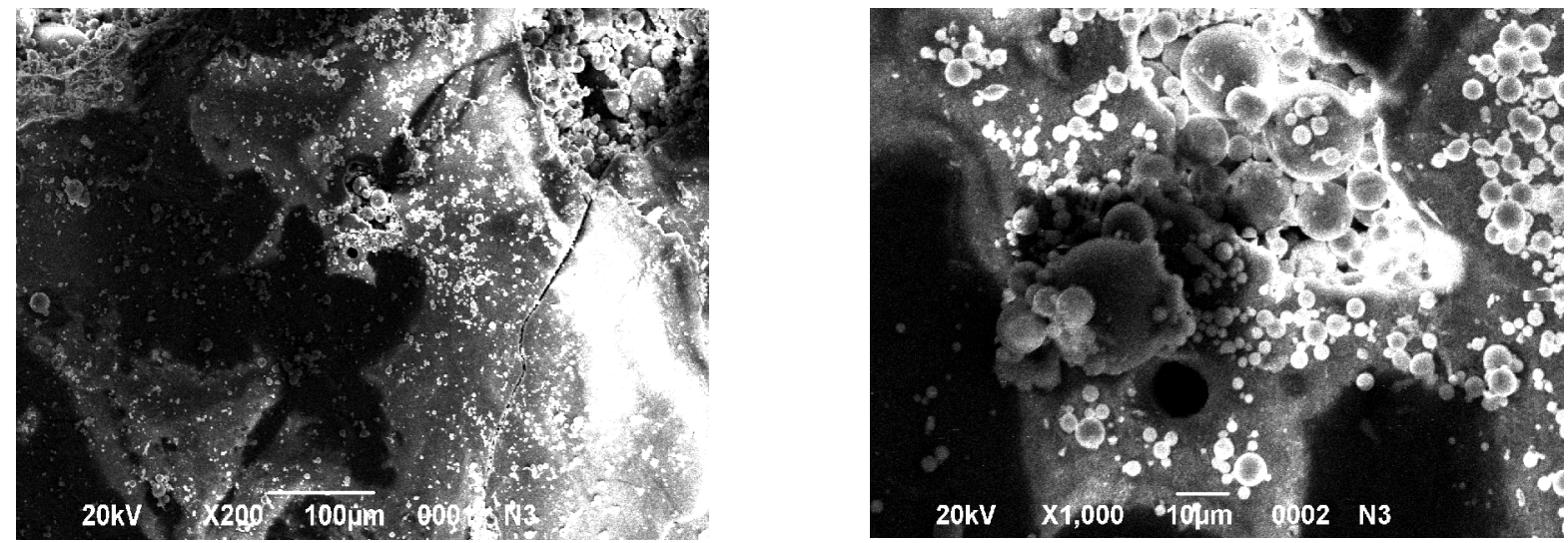

Fig. 2. The particles surface of the 10-20 mm fraction of the Slovianska TTP ash-slag. Magnification of 200x (a) and 1000x (b)

\subsection{X-ray Analysis of Ash-Slag Wastes}

The X-ray analysis of ash-slag wastes from the Slovianska TTP was carried out on the powder diffractometer Siemens D500 in copper radiation with the graphite monochromator. Full-profile diffractograms were measured within the angle range $5<2 \theta<120^{\circ}$ in increments and $0.02^{\circ}$. The accumulation time is $15 \mathrm{~s}$ at each point. The primary phase identification was performed using the catalog PDF-1 [14].

The received roentgenograms of the Slovianska TTP ash-slag wastes fractions confirm that all three fractions are mostly made of glass-like materials. They have no crystal structure; therefore, the detailed analysis of phases is impossible. Some separate lines can be seen on the wavy background of the roentgenograms (Fig. 3). They are not identical on all three roentgenograms. It can be assumed that these glasses contain some crystallized phases.

The fractions $<5 \mathrm{~mm}$ and $10-20 \mathrm{~mm}$ contain compounds of iron and pure iron. They stipulate the increase of the fraction density and the magnetic component of particles. A considerable decrease of hydraulic activity of melted particles is explained by availability of iron oxide. At the same time, they can serve as catalysts of silicon forming reactions when ash-slag fractions are used as an active addition to cement.

The presence of calcium aluminate $\mathrm{CaO} \cdot 2 \mathrm{Al}_{2} \mathrm{O}_{3}$ is a peculiar feature of the mineral composition of the crystal phase of the fraction of $5-10 \mathrm{~mm}$. This mineral is hydraulically active; the product of its hardening shows increased resistance to the action of many aggressive environments. It is the basic mineral component of clay cement. It is mineralogical parameters, not the chemical composition, that play a considerable role in determination of potential ability to hydration.

Measuring of acidity of the water film layer on the surface of solid particles has shown that particles of the fraction $<5 \mathrm{~mm}$ and 5-10 mm have acidic reaction: $\mathrm{pH}$ equals 4.47 and 4.22 accordingly. For particles of the fraction 10 $20 \mathrm{~mm}$ the film layer of water is practically neutral, the value of $\mathrm{pH} 5.82$ is close to that for distilled water.

The possibility of using slag from the Slovianska TTP as an artificial filler of concretes is not denied. In this 
case grains of the irregular form broken down thermally and mechanically can become the basic filler, partially replace crushed stone $(20-60 \%)$ or improve granulometry of fine sand. The granulometry of slag is very important, especially when it is used as a basic filler [15]. It can be noted that the strength of fractions of $5-10 \mathrm{~mm}$ is $33-$ $34 \%$ higher and crushing ability is $24-38 \%$ lower than the same parameters for fractions of $10-20 \mathrm{~mm}$.
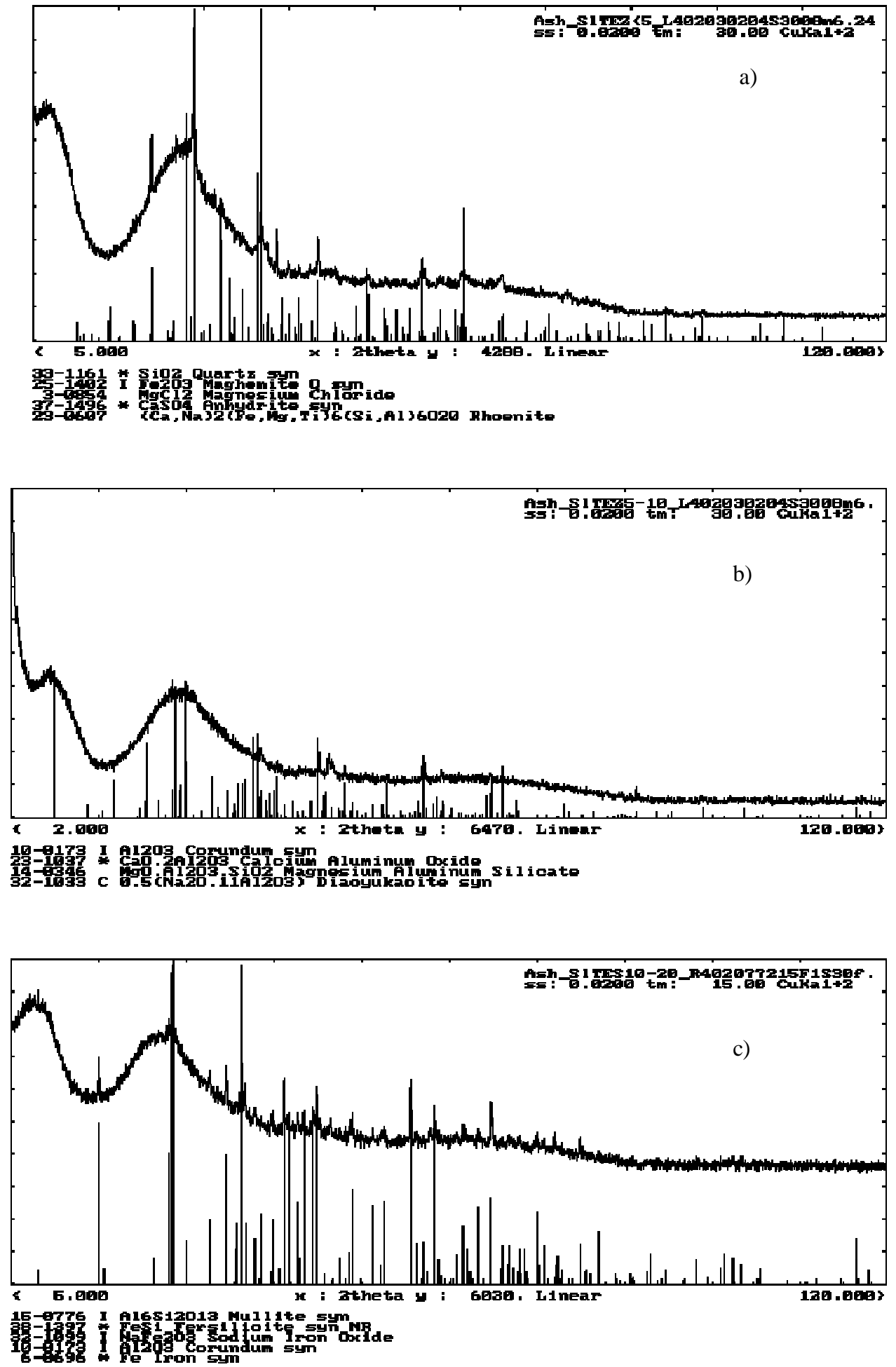

Fig. 3. The roentgenogram of the Slovianska TTP ash-slag fractions, mm: $<5$ (a); 5-10 (b) and 10-20 (c) 
The oxide composition (mass \%) of the Slovianska TTP ash-slag

\begin{tabular}{|c|c|c|c|}
\hline Oxide Fraction, $\mathrm{mm}$ & $<5$ & $5-10$ & $10-20$ \\
\hline $\mathrm{SiO}_{2}$ & 54.3 & 58.4 & 58.4 \\
\hline $\mathrm{Al}_{2} \mathrm{O}_{3}$ & 21.3 & 24.4 & 25.9 \\
\hline $\mathrm{Fe}_{2} \mathrm{O}_{3}$ & 11.3 & 11.5 & 9.36 \\
\hline $\mathrm{CaO}$ & 2.79 & 2.79 & 3.86 \\
\hline $\mathrm{MgO}$ & 1.33 & 1.20 & 0.82 \\
\hline$M_{m}$ & 0.186 & 0.173 & 0.157 \\
\hline
\end{tabular}

\subsection{Chemical Analysis}

The results of the chemical analysis have shown that the major oxide of the Slovianska TTP ash-slag is $\mathrm{SiO}_{2}$ (Table 3). Then, in order of decreasing quantitative content it is followed by $\mathrm{Al}_{2} \mathrm{O}_{3}, \mathrm{Fe}_{2} \mathrm{O}_{3}, \mathrm{CaO}$, and $\mathrm{MgO}$. With enlarging fractions, the quantitative content of $\mathrm{SiO}_{2}$ increases by $7 \%, \mathrm{Al}_{2} \mathrm{O}_{3}-17.7 \%$ and $\mathrm{CaO}-27.7 \%$. Simultaneously the content of $\mathrm{Fe}_{2} \mathrm{O}_{3}$ and $\mathrm{MgO}$ oxides decreases by 18.6 and $38.3 \%$, respectively.

The calculated module of melting $M_{m}$ (Table 3 ) is an important quantitative characteristic of ash fusibility:

$$
M_{m}=\left(\mathrm{CaO}+\mathrm{Fe}_{2} \mathrm{O}_{3}\right):\left(\mathrm{SiO}_{2}+\mathrm{Al}_{2} \mathrm{O}_{3}\right)
$$

Since ash microporosity is connected with fusion viscosity, it depends on the specified oxides relationship. Literary data [12] prove that with decreasing $M_{m}$ the temperature of ash fusion reduces and its microporosity decreases. The adsorption activity and ash microporosity depend on $M_{m}$ much more than on slag particles. When using ashes of the Slovianska TTP in light concretes it is necessary to take into consideration their water saturation, especially when they are used in construction. The factor of heat conductivity can be increased by $5-10$ times with full water saturation compared to dry concretes. Proceeding from these statements dropping $M_{m}$ will provide lower water saturation of light concretes. Thus, from the range of the investigated fractions large fractions of 5-10 $\mathrm{mm}$ and $10-20 \mathrm{~mm}$ are more suitable to be used in light concretes.

\section{Conclusions}

The results of the research have shown that the elemental composition of fractions is different; fractions include glass as a material without the crystal structure; the fractions $<5 \mathrm{~mm}$ and $5-10 \mathrm{~mm}$ have an acidic reaction and the fraction $10-20 \mathrm{~mm}$ is neutral; there are also differences in granulometrical properties of slag fractions; materials can be used in construction without any restriction. All the above-mentioned as well as differences of the mineral structure of the crystal phase of fractions point to various areas of fractions application as components of light concretes.
The fraction $<5 \mathrm{~mm}$ is recommended to be used as an active additive to cement. The fractions $5-10 \mathrm{~mm}$ and $10-20 \mathrm{~mm}$ can be used as fine fillers of light concretes.

\section{References}

[1] Lieuw Kie Song M.R.: Work 2001: First International Conference of Employment Creation in Development, South Africa, Witwatersrand 2001, 11.

[2] Malhotra S., Tehri S.: Indian J. Eng. Mat. Sci., 1995, 2, 80.

[3] Eguchi K: P. Jpn. Concrete Inst., 2011, 33, 761.

[4] Khobotova E., Kalmykova Yu.: Zaschita Okruzhaushei Prirodnoi Sredy pri Utilizatsii Otvalnykh Domennykh Shlakov v Proizvodstve Stroitelnykh Materialov. XNADU, Kharkov 2014.

[5] Wang H., Qi C., Farzam H., Turici J.: Concrete Int., 2006, 28, 47.

[6] Malhotra V., Mehta P.: High-Performance, High-Volume Fly Ash Concrete. Supplementary Cementing Materials for Sustainable Development Inc., Ottawa 2005.

[7] Thomas M.: Optimizing the Use of Fly Ash in Concrete. Portland Cement Association, Publication IS 548, 2007.

[8] Karthik H.: Concrete InFocus, 2008, 60.

[9] Naik T., Ramme B., Kraus R., Siddique R.: ACI Mat. J., 2003, 100, 150 .

[10] Khobotova E., Ukhaniova M., Graivoronskaya I., Kalmykova Yu.: Radiatsionno-Khimicheskoe Obosnovanie Ispolzovaniya Tverdykh Promyshlennykh Othodov v Kachestve Technicheskikh Materialov. XNADU, Kharkov 2011.

[11] Khobotova E., Larin V., Ignatenko M., Kalmykova Yu.: Radioecologicheskyi Monitoring Syrievykh Materialov Stroitelnoi Otrasli. XNADU, Kharkov 2016.

[12] Ivanov I.: Legkie Betony s Primeneniem Zol Electrostanciy. Stroiizdat. Moskva 1986.

[13] zakon.rada.gov.ua/laws/show/v4422400-87

[14] JCPDS PDF-1 File. International Committee for Diffraction Data, release 1994. PA, USA

[15] Sergeev A.: Ispolzovanie $\mathrm{v}$ Stroitelstve Othodov Energeticheskoi Promyshlennosti. Budivelnyk, Kyiv 1984.

Received: M arch 17, 2016 / Revised: April 18, 2016 / Accepted: September 12, 2016

\section{ЕЛЕМЕНТНИЙ I МІНЕРАЛЬНИЙ СКЛАД ЗОЛОШЛАКОВИХ ВІДХОДІВ СЛАВ'ЯНСЬКӦ̈ ТЕС}

Анотація. Визначено елементний, мінеральний $i$ радіонуклідний склад золочлаків Слав'янської ТЕС. Фракиї золошлаків відповідають першому класу радіаційної безпеки. Кількісний оксидний склад наступний: $\mathrm{SiO}_{2}, \mathrm{Al}_{2} \mathrm{O}_{3}, \mathrm{Fe}_{2} \mathrm{O}_{3}, \mathrm{CaO} i$ $\mathrm{MgO}$. Гранулометричні фракиії відходів можуть бути рекомендовані як компоненти легких бетонів.

Ключові слова: паливна зола, илак, фракиія, мінерал, радіоактивність. 